\title{
BMJ Open Quality appraisal of clinical guidelines for venous thromboembolism prophylaxis in patients undergoing hip and knee arthroplasty: a systematic review
}

\author{
Yu Wang, ${ }^{1}$ Li-Yun Zhu, ${ }^{1}$ Hai-Bo Deng, ${ }^{2}$ Xu Yang, ${ }^{3}$ Lei Wang, ${ }^{4}$ Yuan $X u,{ }^{3}$ \\ Xiao-Jie Wang, ${ }^{5}$ Dong Pang, ${ }^{6,7}$ Jian-Hua Sun, ${ }^{8}$ Jing Cao, ${ }^{1}$ Ge Liu, ${ }^{9}$ Ying Liu, ${ }^{10}$ \\ Yu-Fen Ma, ${ }^{11}$ Xin-Juan Wu (i) ${ }^{1}$
}

To cite: Wang Y, Zhu L-Y, Deng H-B, et al. Quality appraisal of clinical guidelines for venous thromboembolism prophylaxis in patients undergoing hip and knee arthroplasty: a systematic review. BMJ Open 2020;10:e040686. doi:10.1136/ bmjopen-2020-040686

- Prepublication history and additional materials for this paper is available online. To view these files, please visit the journal online (http://dx.doi. org/10.1136/bmjopen-2020040686).

Received 19 May 2020 Revised 25 0ctober 2020 Accepted 05 November 2020

Check for updates

(c) Author(s) (or their employer(s)) 2020. Re-use permitted under CC BY-NC. No commercial re-use. See rights and permissions. Published by BMJ.

For numbered affiliations see end of article.

Correspondence to

Dr Xin-Juan Wu;

wuxinjuan@sina.com and

Dr Yu-Fen Ma;

yumafen@126.com

\section{ABSTRACT}

Introduction Venous thromboembolism (VTE) occurs in up to $40 \%-80 \%$ of patients after hip and knee arthroplasty. Clinical decision-making aided by guidelines is the most effective strategy to reduce the burden of VTE. However, the quality of guidelines is dependent on the strength of their evidence base. The objective of this article is to critically evaluate the quality of VTE prevention guidelines and the strength of their recommendations in VTE prophylaxis in patients undergoing hip and knee arthroplasty.

Methods Relevant literature up to 16 March 2020 was systematically searched. We searched databases such as Web of Science, PubMed, EMBASE, Cumulative Index of Nursing and Allied Health Literature, China National Knowledge Infrastructure and WanFang and nine guidelines repositories. The identified guidelines were appraised by two reviewers using the Appraisal of Guidelines for Research and Evaluation II and appraised the strength of their recommendations independently. Following quality assessment, a predesigned data collection form was used to extract the characteristics of the included guideline.

Results We finally included 15 guidelines. Ten of the included guidelines were rated as 'recommended' or 'recommended with modifications'. The standardised scores were relatively high in the domains of Clarity of Presentation, and Scope and Purpose. The lowest average standardised scores were observed in the domains of Applicability and Stakeholder Involvement. In reference to the domains of Rigour of Development and Editorial Independence, the standardised scores varied greatly between the guidelines. The agreement between the two appraisers is almost perfect (intraclass correlation coefficients higher than 0.80 ). A considerable proportion of the recommendations is based on low-quality or very-lowquality evidence or is even based on working group expert opinion.

Conclusions In summary, the majority of the recommendations are based on low-quality evidence, and further confirmation is needed. Furthermore, guideline developers should pay more attention to methodological quality, especially in the Stakeholder Involvement domain and the Applicability domain.
Strengths and limitations of this study

- Our research critically evaluated the quality of guidelines for prevention of venous thromboembolism (VTE) in patients undergoing elective hip and knee arthroplasty and the strength of their recommendations in VTE prophylaxis.

- Two appraisers used Appraisal of Guidelines for Research and Evaluation II, an assessment with methodological rigour and reliability, to appraise the quality of included guidelines and resolved any discrepancies by discussion.

- Our search strategy was also reproducible; however, because of language or publication restrictions, there may be a language barrier.

\section{INTRODUCTION}

Total knee arthroplasty (TKA) and total hip arthroplasty (THA) are widely regarded as effective treatment options for patients with joint failure, which can help alleviate pain and improve function. ${ }^{1-3}$ Despite considerable advances in surgical and anaesthetic techniques, patients undergoing TKA and THA are at high risk of venous thromboembolism (VTE), manifesting as deep vein thrombosis or pulmonary thromboembolism. ${ }^{4}$ VTE is a severe postoperative complication, which commonly occurs in $40 \%-80 \%$ of patients undergoing THA and TKA. ${ }^{5}$ VTE is a potentially preventable medical condition that can prolong hospital stays and increase mortality. ${ }^{6}$ Despite the cost-effectiveness of THA and TKA, in-hospital cost and rehabilitation cost associated with hospital-acquired VTE place significant burdens on global healthcare systems. ${ }^{7}$

Using evidence-based VTE programmes can improve practice outcomes while reducing the physical, psychological, social and economic burden on individuals, families 
and countries. Clinical practice guidelines (CPGs) enable health professionals and patients to make the best decisions about treatment or care for a particular condition or situation and reduce waste. However, the quality of a CPG is dependent on the strength of its evidence base. ${ }^{8}$ As such, there is a need to evaluate CPGs to assess their quality. Therefore, we undertook this systematic review to evaluate the quality of the CPGs and the strength of their recommendations in VTE prophylaxis.

\section{METHODS}

\section{Objectives}

The purpose of this systematic review is to critically appraise the quality of VTE prevention guidelines specific to the patients after THA and TKA. The Appraisal of Guidelines for Research and Evaluation II (AGREE II) tool was used. We wrote this study following Preferred Reporting Items for Systematic Review and Meta-Analysis 2009 statement $^{9}$ (see online supplemental table 1).

\section{Data sources and search strategy}

Academic databases, including Web of Science, PubMed, EMBASE, Cumulative Index of Nursing and Allied Health Literature, and Chinese databases (China National Knowledge Infrastructure and WanFang), were searched from inception until 16 March 2020. The search strategy was tailored to the requirements of each database. Searching of reference lists from identified papers was carried out along with forwarding citation searching using Google Scholar. All searches were saved in each database and imported into EndNote (V.X9; Clarivate Analytics), where duplicates were removed. To supplement our database searches, we also searched guidelines repositories, including CPG Infobase: Clinical Practice Guidelines (Canadian Medical Association), the Guidelines International Network, the National Health and Medical Research Council-Australian Clinical Practice Guidelines, the National Institute for Health and Care Excellence (NICE), the National Guideline Clearinghouse, Scottish Intercollegiate Guideline Network, New Zealand Guidelines Group, BMJ Best Practice and Chinese guidelines repository (YiMaiTong). Details of the searches are provided in online supplemental appendix 1 .

\section{Eligibility criteria}

A complete list of inclusion and exclusion criteria is detailed in table 1 .

\section{Data screening and extraction}

Two reviewers used prespecified eligibility criteria to screen titles and abstracts. Articles that met the above inclusion and exclusion criteria were included for a second full-text screen. Conflicts were resolved through discussion or the involvement of a third reviewer. Reasons for exclusion were documented in a tabular format (online supplemental appendix 2). Data extraction was
Table 1 Inclusion and exclusion criteria

\section{No. Items}

Inclusion criteria

1 Published international and national guidelines on the management and/or prevention of VTE after THA or TKA

$\begin{array}{ll}2 & \text { Published as full text } \\ 3 & \text { Guidelines published in Chinese or English } \\ 4 & \begin{array}{l}\text { Most recent complete guideline (from a single working } \\ \text { group, ie, ACCP) and any partial revisions for the }\end{array} \\ \text { guideline published thereafter }\end{array}$

\section{Exclusion criteria}

1 Guidelines under development

2 Guidelines were specific to one institution

3 Complete guidelines with publication dates that have been superseded by more recent complete guidelines

4 Guidelines that only cover one aspect of VTE prevention (ie, anticoagulant prophylaxis)

5 Clinical practice standards, defined as a statement reached through consensus, which identifies the desired outcome. Usually used in audit as a measure of success ${ }^{47} 48$

6 Guidelines inclusive of only one phase of care, for example, Ginzburg et al $^{49}$ (ie, during rehabilitative therapy)

ACCP, American College of Chest Physicians; THA, total hip arthroplasty; TKA, total knee arthroplasty; VTE, venous thromboembolism.

then performed independently using a standardised data extraction form developed based on AGREE II. ${ }^{10}$

\section{Quality assessment of CPGs}

To evaluate the quality of pre-existing guidelines selected for guideline adaptation, two reviewers graded each guideline according to AGREE II. ${ }^{11}$ This instrument consists of 23 items organised into six domains. AGREE II also includes two overall assessment items for overall judgements of the practice guideline. Online supplemental appendix 3 provides a brief description of each domain.

The 23-item AGREE II tool uses a seven-point agreement scale from 1 (strongly disagree) to 7 (strongly agree). ${ }^{10}$ Standardised scores for each domain were computed as $(\mathrm{X} / \mathrm{Y}) \times 100 \%$, where $\mathrm{X}=$ obtained scoreminimum possible score and $\mathrm{Y}=$ maximum possible score-minimum possible score. ${ }^{10}$ As defined by AGREE II, we considered a CPG as 'recommended' if it scored above $50 \%$ on $\geq 4$ domains, as 'recommended with modifications' if it scored above $50 \%$ on 3 domains and as 'not recommended' if it scored less than $50 \%$ on $\geq 4$ domains.

Before the quality appraisal using AGREE II, two reviewers completed an Online Training Tool $^{12}$ and 


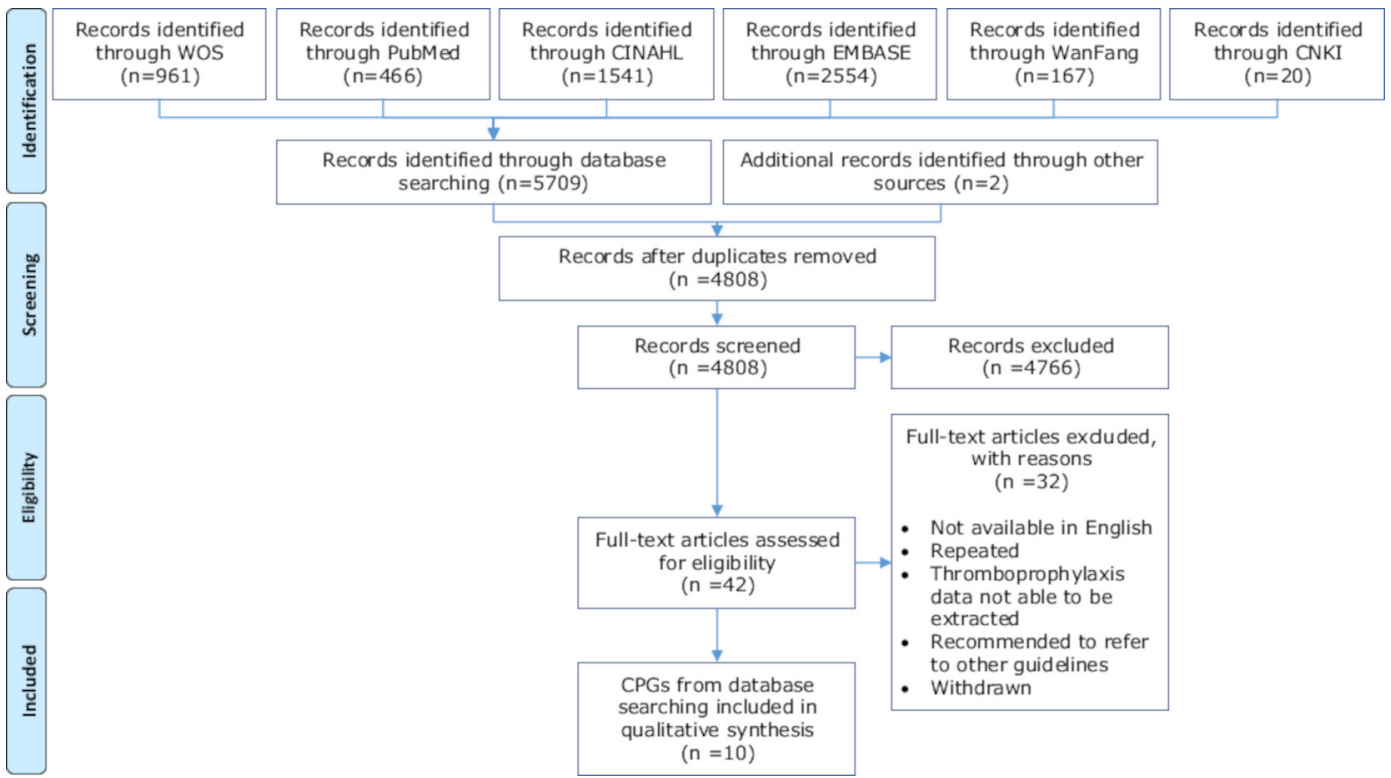

Figure 1 Search strategy for library databases (final search undertaken on 16 March 2020). CPGs, clinical practice guidelines; CINAHL, Cumulative Index of Nursing and Allied Health Literature; WOS, Web of Science; CNKI, China National Knowledge Infrastructure.

performed calibration exercises to clarify the eligibility criteria. Following training, the two reviewers independently applied AGREE II criteria to eligible CPGs using the My AGREE PLUS online platform. ${ }^{13}$ Our team met regularly to resolve any discrepancies in the quality appraisal. We used intraclass correlation coefficients (ICCs) to measure the agreement between the two assessors' assessment of quality (AGREE II) of included CPGs. The results were interpreted as follows: 0.00 , poor agreement; $0.00-0.20$, slight agreement; $0.21-0.40$, fair agreement; $0.41-0.60$, moderate agreement; $0.61-0.80$, substantial agreement; and 0.81-1.00, almost perfect agreement. $^{14}$

\section{RESULTS}

The electronic database search retrieved 4808 citations. We retrieved and assessed the full texts of 42 promising reports, and among these, we excluded 32 (figure 1). The guidelines repositories search retrieved 327 citations, of which 317 full texts were excluded (figure 2). In total, 15 guidelines were included in the final analysis, and the detailed characteristics are shown in table 2. These CPGs were published between 2006 and 2019. Most of the CPGs were developed in the USA ( $n=3),{ }^{15-17}$ with the remaining coming from China $(\mathrm{n}=1),{ }^{18}$ the UK $(\mathrm{n}=1),{ }^{19}$ France $(\mathrm{n}=1),{ }^{20}$ Poland $(\mathrm{n}=1),{ }^{21}$ Malaysia $(\mathrm{n}=1),{ }^{22}$ Korea $(\mathrm{n}=1),{ }^{23}$ Italy $(\mathrm{n}=1),{ }^{24}$ Scotland $(\mathrm{n}=1)^{25}$ and Southern Africa $(n=1),{ }^{26}$ or from Asia $(n=1),{ }^{27}$ Europe $(n=1)^{28}$ or International $(\mathrm{n}=1){ }^{29}$ Information sources regarding where CPGs were obtained are shown in online supplemental appendix 4 .

Two assessors appraised each CPG. The AGREE II domain scores of each guideline are presented in table 3. Detailed scoring of each AGREE II item under each domain is presented in online supplemental appendix 5 . Online supplemental figure 1 shows a radar chart of the results of the guideline appraisal. The quality of the evaluated guidelines showed significant variability. The standardised scores ranged from $50 \%$ to $100 \%$ in the Scope and Purpose domain, and all CPGs scored above $50 \%$. The standardised scores in the Stakeholder Involvement domain ranged from $3 \%$ to $89 \%$, with 6 of 15 CPGs scoring above $50 \%$. The standardised scores in the Rigour of Development domain ranged from $16 \%$ to $98 \%$, with 8 of 15 CPGs scoring above $50 \%$. The standardised scores in the Clarity of Presentation domain ranged from $42 \%$ to $100 \%$, with only one CPG scoring below $50 \%$. The standardised scores in the Applicability domain ranged from $4 \%$ to $94 \%$, with only 2 of 15 CPGs scoring above $50 \%$. The standardised scores in the Editorial Independence domain ranged from $0 \%$ to $92 \%$, with 8 of 15 CPGs scoring above $50 \%$. Per the quality assessment tool used in this review, 6 of the 15 included CPGs were judged to be 'recommended'. There is an almost perfect agreement between two appraisers, with the ICC ranging from 0.875 to 0.955 .

Table 4 shows the levels of evidence for recommendations of VTE prevention in patients undergoing THA or TKA, as reported in the included CPGs. There are four CPGs developed using the Grading of Recommendations, Assessment, Development, and Evaluation (GRADE) system to rank recommendations. ${ }^{15} 162328$ Comparatively, four CPGs were developed based on expert opinion. ${ }^{18} 262729$ Despite unanimous agreement in the recommendations for providing pharmacological and/ or mechanical prophylaxis, early or delayed prophylaxis, and extended duration of prophylaxis, details disagree on the pharmacological and mechanical prophylaxis 


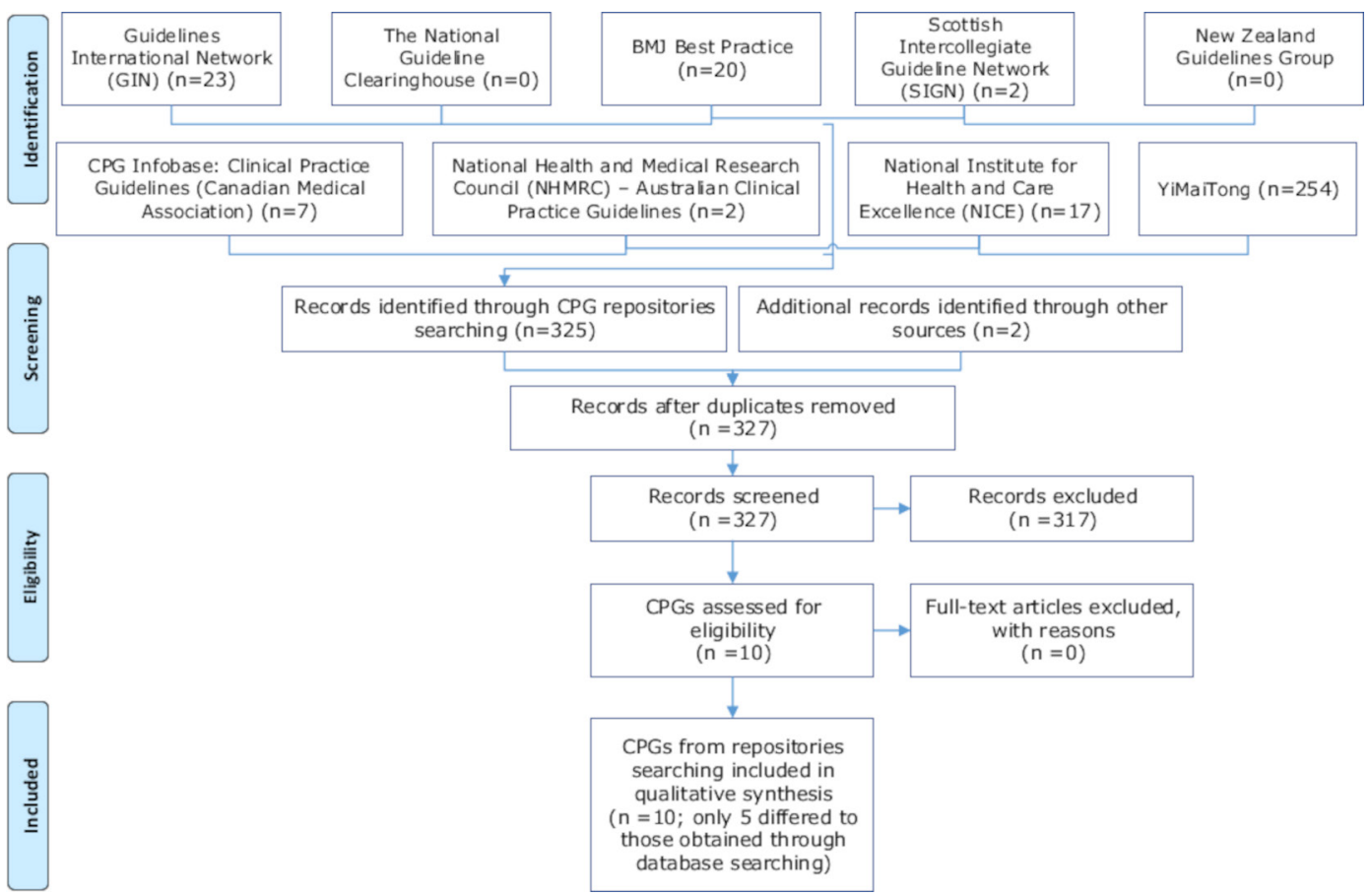

Figure 2 Search strategy for guideline repositories (final search undertaken on 16 March 2020). CPGs, clinical practice guidelines.

choice, time of early or delayed prophylaxis, and duration of prophylaxis. The American College of Chest Physicians (ACCP) 2012 guidelines ${ }^{16}$ European Society of Anaesthesiology (ESA) 2017 guidelines ${ }^{28}$ and French Society for Anaesthesiology and Intensive Care (FSAIC) 2006 guidelines $^{20}$ recommended low-molecular-weight heparin $(\mathrm{LMWH})$ as a preference pharmacological prophylaxis choice, whereas direct oral anticoagulants (DOACs) were recommended in the American Society of Hematology (ASH) 2019 guidelines. ${ }^{15}$ An extended duration of thromboprophylaxis of 35 days in patients undergoing THA and 14 days in patients undergoing TKA seemed to be the primary choice. ${ }^{1618192126}$ In terms of improving CPG implementation, patient/family education, type of anaesthesia, risk assessment and bridging therapy, we observed little recommendations with very low quality. The recommendations from each CPG that are informed in table 4 are detailed in online supplemental appendix 6 . Online supplemental appendix 7 shows an explanation of the different evidence levels used across included CPGs.

\section{DISCUSSION}

To our knowledge, this is the first systematic quality appraisal of CPGs for VTE prevention in patients undergoing THA and TKA. Finally, 15 guidelines were recognised. Generally, the quality of $67 \%(10 / 15)$ of included guidelines was acceptable and evaluated as 'recommended' or 'recommended with modifications'. The included CPGs were consistent in the recommendations, whereas they used different classification systems in indicating the levels of evidence. The data availability of trials and the timing of approval by regulatory agencies may also explain some differences in the preferred pharmacological prophylaxis (such as LMWH or DOACs). It is worth noting that a considerable proportion of the recommendations is based on low-quality or very-lowquality evidence or is even based on working group expert opinion, representing uncertain clinical significance. Therefore, high-quality randomised controlled trials are needed to support the evidence and potentially improve the cost-effectiveness of treatment. ${ }^{30}$ Notably, in terms of patient/family education and improving CPG implementation, very few strong recommendations were identified, indicating a lack of robust evidence. These findings would explain why VTE prophylaxis is still not routinely administered as guideline recommended in most hospitals. ${ }^{31} 32$

The standardised scores varied between different domains. In the Scope and Purpose domain and the Clarity of Presentation domain, the standardised scores were relatively high. In reference to the Rigour of Development domain and Editorial Independence domain, the standardised scores varied considerably between the CPGs. Our results are consistent with the results of other CPG quality appraisal focusing on different clinical topics. ${ }^{33}$ Marked improvements in CPG development methodology over the past decade may have a role in explaining the variance scores. Moreover, guideline development should be carried out according to the formulated plan, such as the WHO Guideline Development Handbook. ${ }^{35}$ It is also recommended to report methodological details for clinical guideline development based on AGREE II. ${ }^{36}$

We found that the domains of Stakeholder Involvement and Applicability were marked with the lowest 


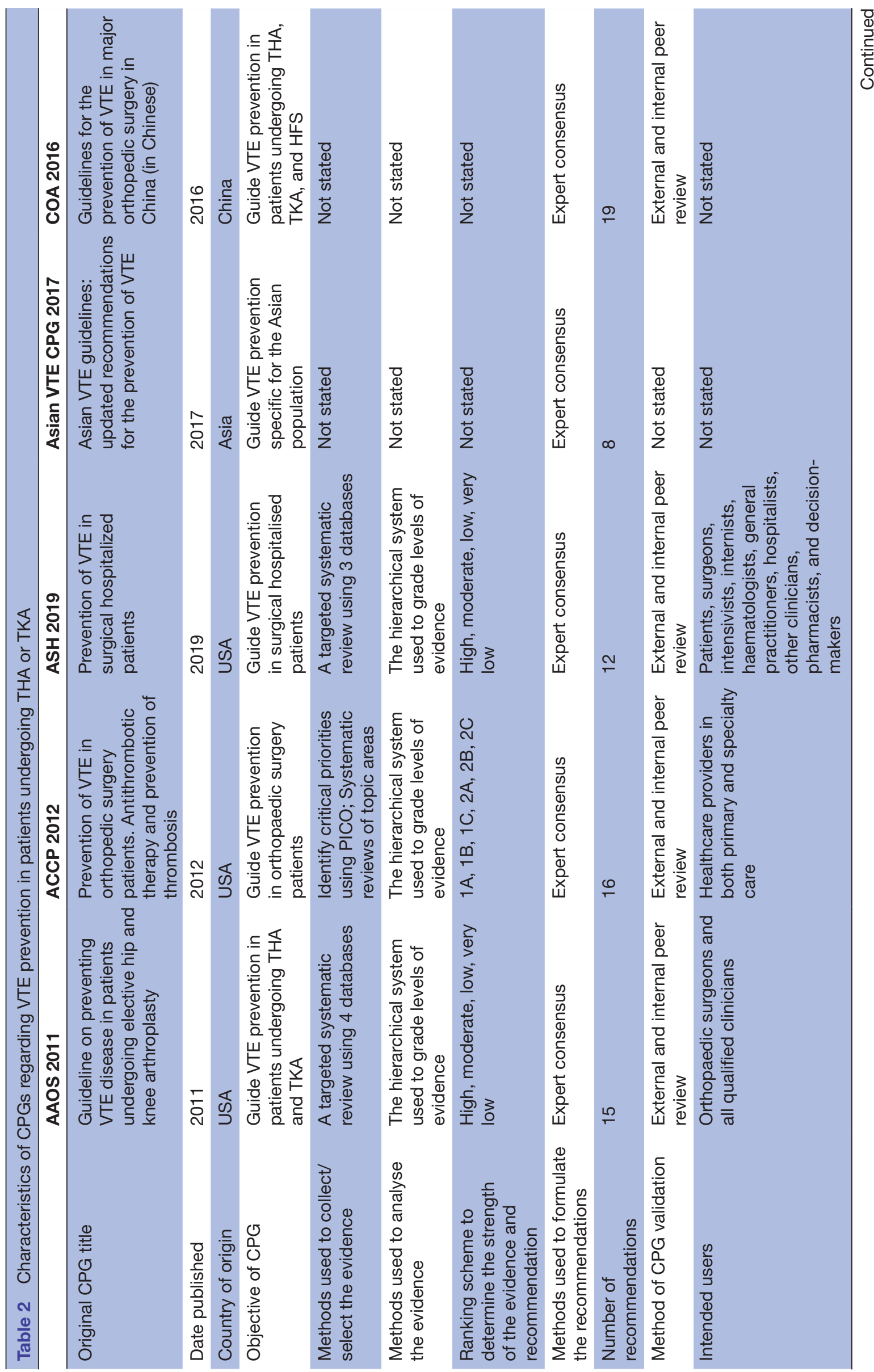




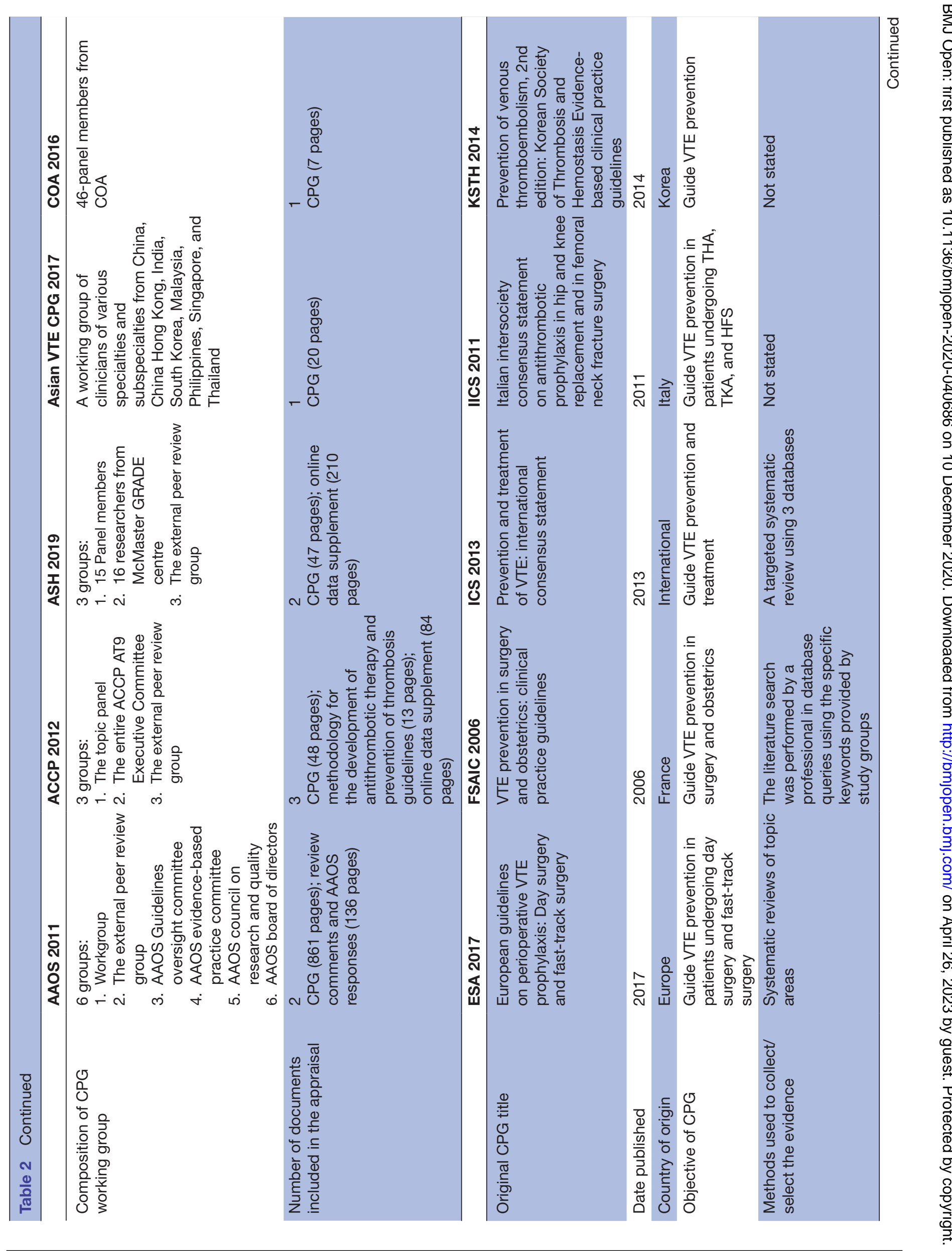




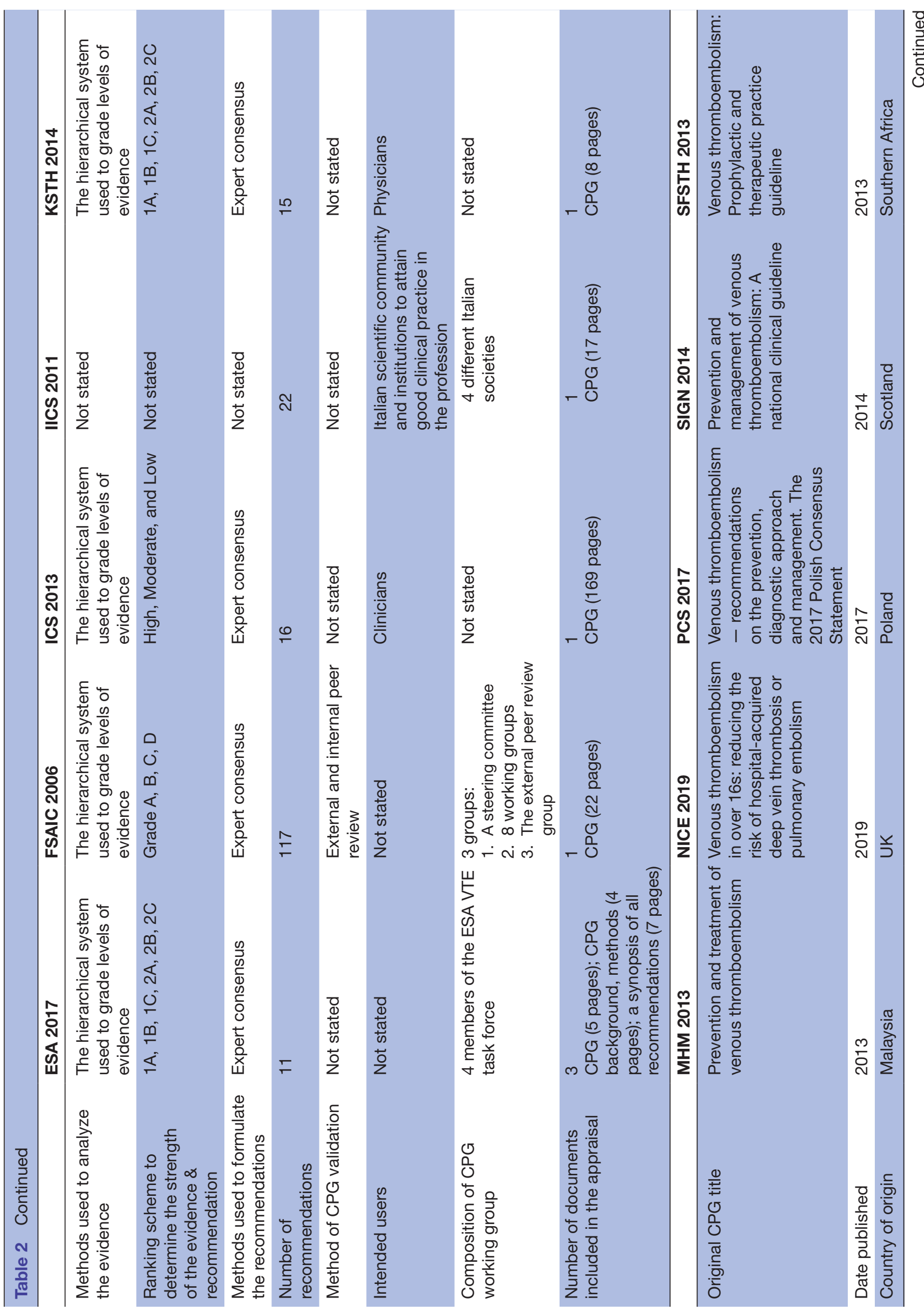




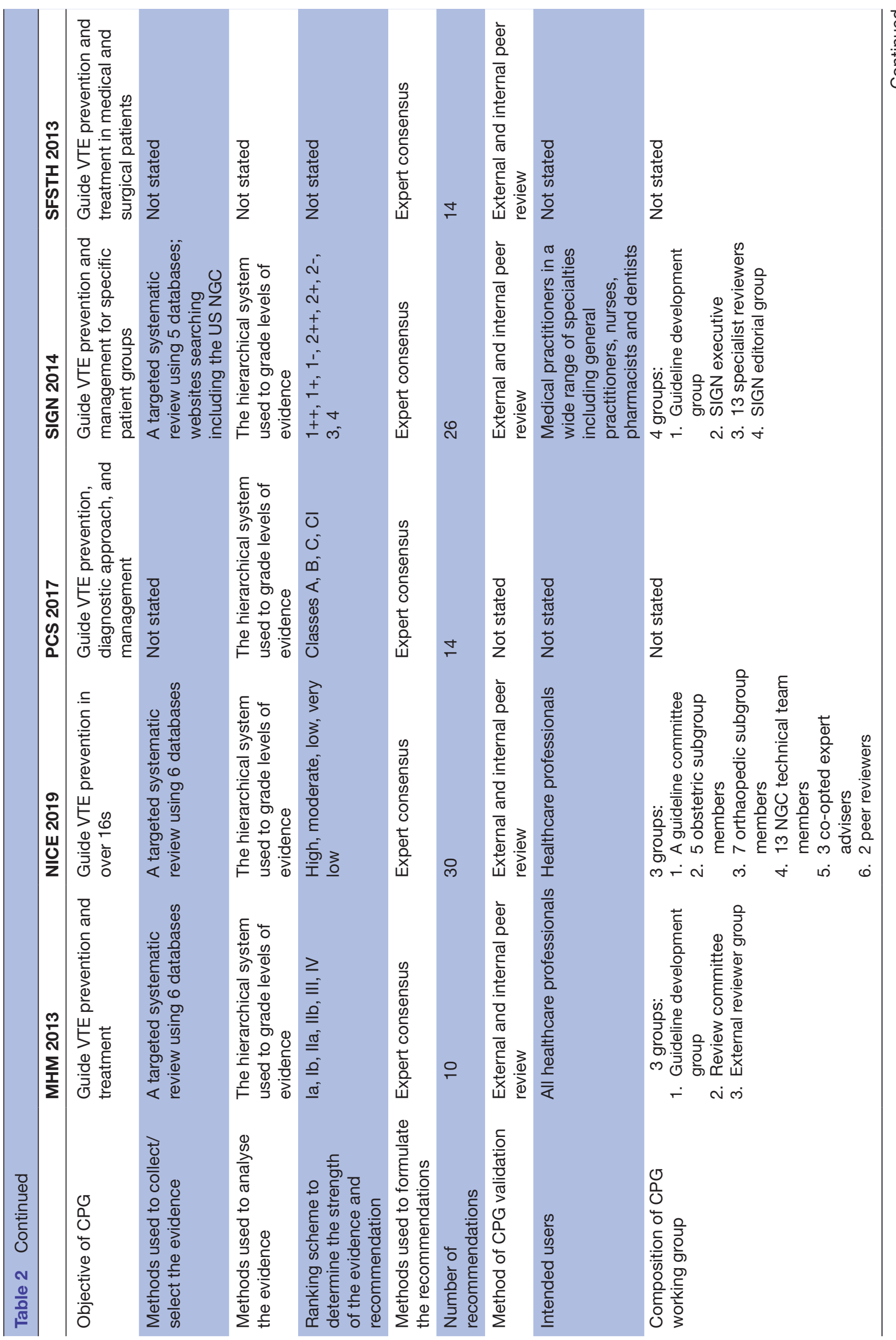




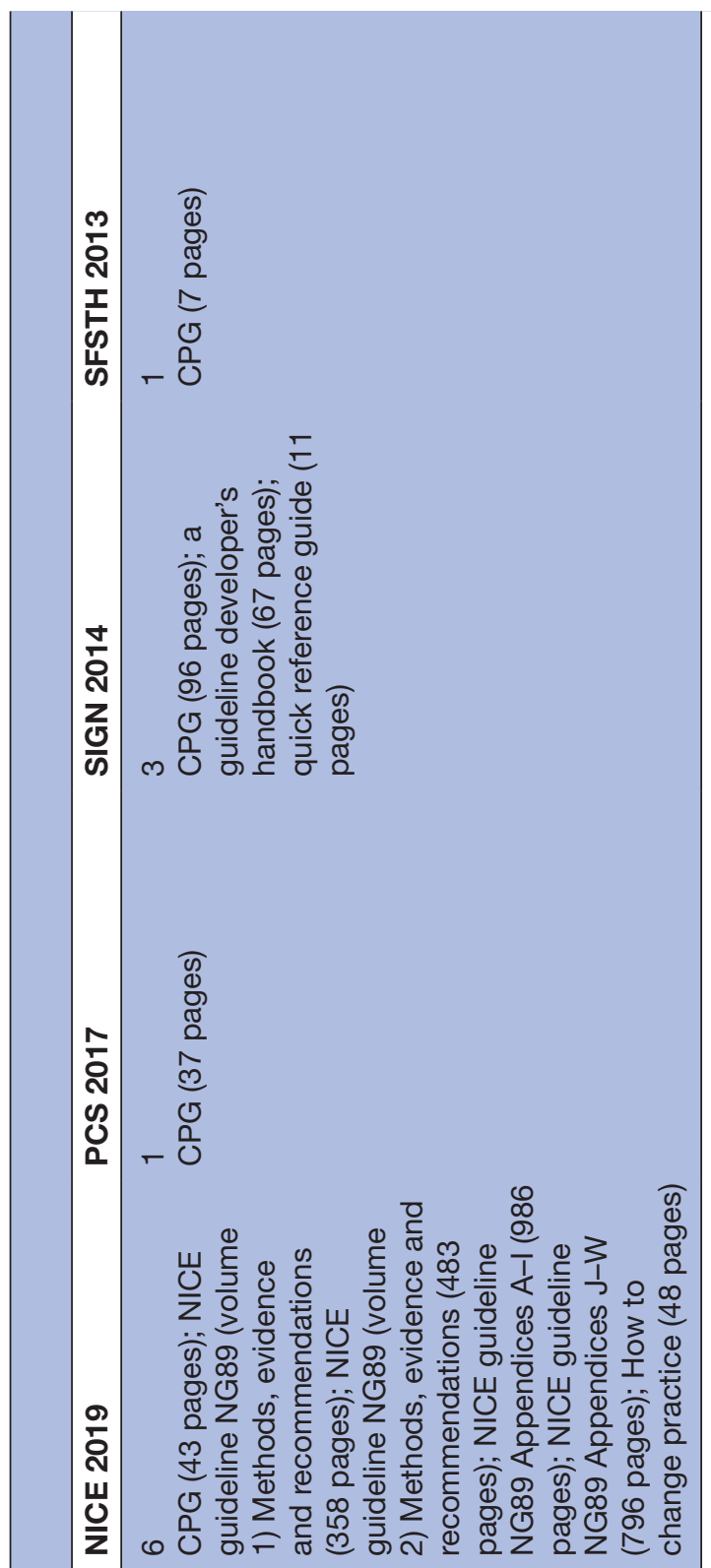

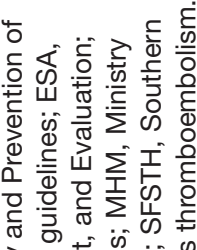

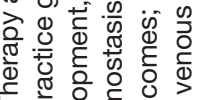

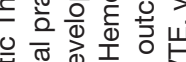

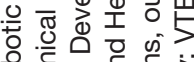

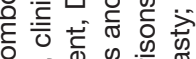
की 完记

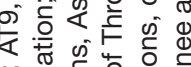

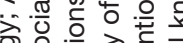
응 की

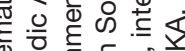

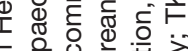

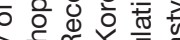

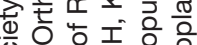
O क 仓ै

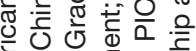
है 过定

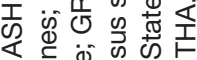

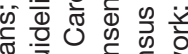
. क 0 क

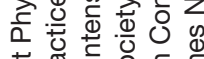
药

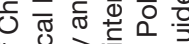

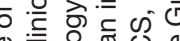

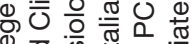
可 웡

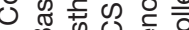
뒁

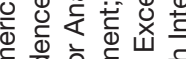

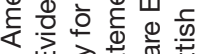

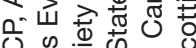

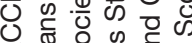
ष. की

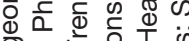
的过员重 क $\frac{0}{0} \frac{0}{0} \frac{\pi}{6}$ 능 ฮ

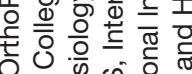

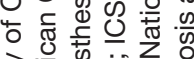
हो ष्ते कृ 这范 की

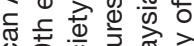
के $\frac{\pi}{\pi}$

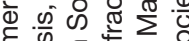
웅으을

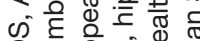

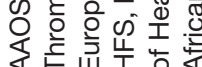




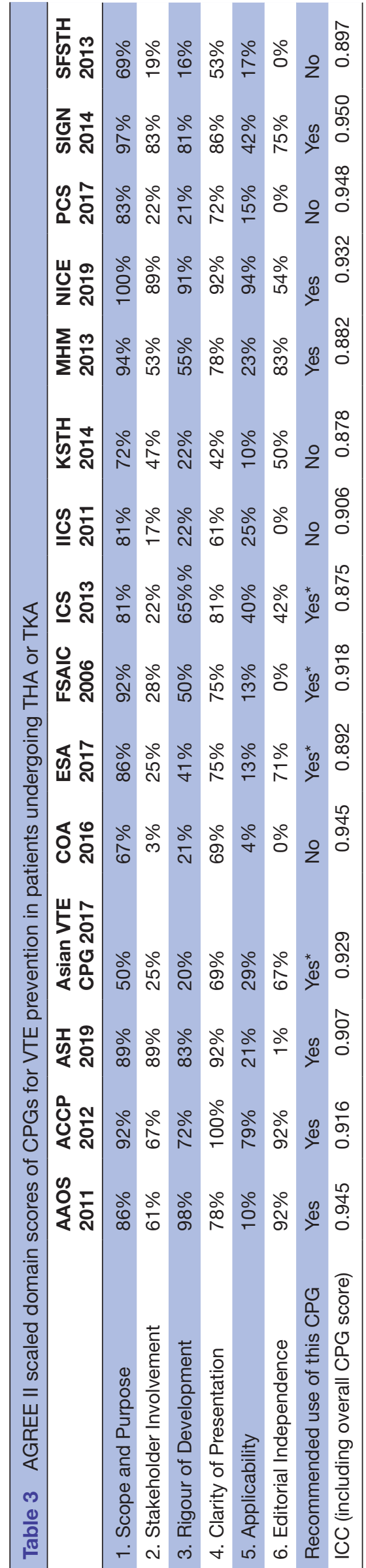

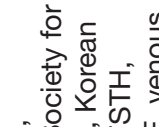

它产

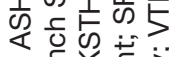

兰至突

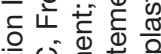

음

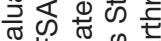

एँ

응

宁응 की

등 क

ఖ

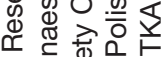

흐

क

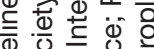

\%

윽

ত ণ

능 ฮำำ

历্

ส

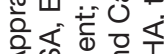

远芯

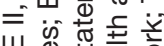

山区 范

品

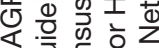

की ठठ⿻ ㇒⿻

त)

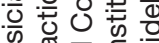

츤 뜨든

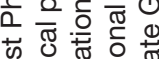

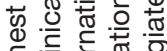

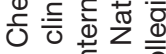

능 出

乐 心

ठํ.

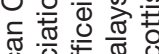

은 융

बै की

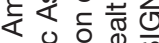

믕 음

U

4 응

in

के

인

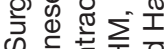

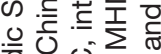

过

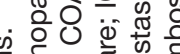

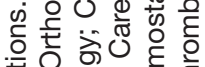

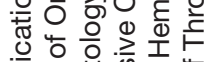

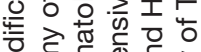

० है है के क्षे

ᄃ

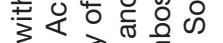

उ क ते ते है क

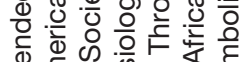

ब足

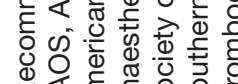

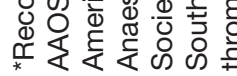

standardised scores, which may be factors influencing implementation. Stakeholder involvement focuses on gaining support from a strong collaborative multidisciplinary network and obtaining the needs of all the potential users. ${ }^{37}$ Indeed, a multidisciplinary approach to VTE prevention involving key stakeholders is essential for putting recommendations into practice. ${ }^{19}$ However, only three CPGs included patients and their representatives in guideline development. ${ }^{151925}$ Evidence-based medicine highlights the importance of patient-centred communication. ${ }^{38}$ Patient values and preferences should be taken into account, and the pros and cons of these options should be discussed with the patient. ${ }^{39}$ Therefore, guideline developers should consider the involvement and engagement of patients and the public in future CPG updates.

Guideline applicability is exceptionally critical for implementation. However, there is a lack of consensus on how CPG should be done in practice. Only two CPGs appraise the barriers and facilitators to guideline implementation and provide strategies to improve guideline uptake. ${ }^{16} 19$ Putting recommendations into practice is always challenging. Examples of multiple evidence-based implementation strategies for preventing VTE have been evaluated, such as computerised reminder systems, education, audit and feedback, and distribution of guidelines. ${ }^{40-44}$ Two published Cochrane systematic reviews have reported the interventions for implementing thromboprophylaxis in hospitalised patients at risk of VTE. ${ }^{4546}$ We call researchers to add the Improve CPG Implementation domain as one of the pillars in guideline development.

This review has some strengths and weaknesses. First, our search strategy was developed with an experienced senior librarian. Our search strategy was also reproducible, as required by systematic reviews of published work. However, because of language or publication restrictions, we may miss some CPGs. Second, the CPGs we included range from 2006 (FSAIC) to 2019 (ASH and NICE). CPGs that are 'recommended' based on the AGREE II scoring could be obsolete if the CPGs are derived from outdated evidence. Therefore, some caution is warranted here. Finally, two appraisers used AGREE II, an assessment with methodological rigour and reliability, to appraise the quality of included guidelines and resolved any discrepancies by discussion. Although the appraisers were inexperienced in guideline evaluation, all had completed the AGREE II online training. Besides, the team members met weekly online to discuss progress and problems. And six of our group members have attended the Joanna Briggs Institute (JBI) evidence-based medicine training courses.

\section{CONCLUSIONS}

In summary, the majority of the recommendations are based on inadequate evidence quality, and further confirmation is needed. Furthermore, guideline developers should pay more attention to methodological quality, especially in the Stakeholder Involvement domain and 
Table 4 Levels of evidence for recommendations of VTE prevention in patients undergoing THA or TKA as reported in included CPGs

\begin{tabular}{|c|c|c|c|c|c|}
\hline Recommendations* & AAOS 2011 & ACCP 2012 & ASH 2019 & $\begin{array}{l}\text { Asian VTE CPG } \\
2017\end{array}$ & COA 2016 \\
\hline $\begin{array}{l}\text { 1. Against routine postoperative } \\
\text { VTE screening }\end{array}$ & Low-High & Grade 1B & - & - & - \\
\hline 2.VTE risk assessment & $\begin{array}{l}\text { VTE history } \\
\text { (Low, } \\
\text { Moderate) } \\
\text { Other } \\
\text { factors } \\
\text { (Very Low- } \\
\text { Moderate) }\end{array}$ & - & - & $\begin{array}{l}\text { NR about primary } \\
\text { thrombophilia (WG) }\end{array}$ & - \\
\hline 3. Bleeding risk assessment & $\begin{array}{l}\text { Bleeding } \\
\text { disorders } \\
\text { and active } \\
\text { liver disease } \\
\text { (Very Low) } \\
\text { Other } \\
\text { factors (Very } \\
\text { Low, Low) }\end{array}$ & - & - & - & $\begin{array}{l}\text { Assess risk factors } \\
(\mathrm{WG})\end{array}$ \\
\hline 4. Bridging therapy & $\begin{array}{l}\text { Discontinuation } \\
\text { of antiplatelet } \\
\text { preoperative } \\
\text { (Moderate- } \\
\text { High) }\end{array}$ & - & - & - & $\begin{array}{l}\text { Discontinuation } \\
\text { of antiplatelet } \\
\text { preoperative (WG) }\end{array}$ \\
\hline $\begin{array}{l}\text { 5. Stopping oestrogen- } \\
\text { containing oral contraceptives or } \\
\text { hormone replacement therapy }\end{array}$ & - & - & - & - & - \\
\hline $\begin{array}{l}\text { 6. Provide pharmacologic and/or } \\
\text { mechanical prophylaxis }\end{array}$ & $\begin{array}{l}\text { WG, Moderate-- } \\
\text { High }\end{array}$ & $\begin{array}{l}\text { pharmacologic } \\
\text { and IPCD } \\
\text { (Grade } 2 \text { C) }\end{array}$ & Very Low, Low & WG & WG \\
\hline $\begin{array}{l}\text { 9. Mechanical prophylaxis } \\
\text { preference choice } †\end{array}$ & NR (WG) & - & $\begin{array}{l}\text { IPCD (Very } \\
\text { Low) }\end{array}$ & - & - \\
\hline $\begin{array}{l}\text { 10. Evaluation of } \\
\text { pharmacological prophylaxis } \\
\text { contraindications }\end{array}$ & - & - & - & - & WG \\
\hline $\begin{array}{l}\text { 11. Evaluation of mechanical } \\
\text { prophylaxis contraindications }\end{array}$ & - & - & - & - & WG \\
\hline $\begin{array}{l}\text { 12. Use the fitted/correct size of } \\
\text { GCS }\end{array}$ & - & - & - & - & - \\
\hline $\begin{array}{l}\text { 13. Correct use of mechanical } \\
\text { prophylaxis }\end{array}$ & - & - & - & - & - \\
\hline 14. Early or delayed prophylaxis & - & $\begin{array}{l}12 \mathrm{~h} \\
\text { preoperative } \\
\text { or } 12 \mathrm{~h} \\
\text { postoperative } \\
\text { (Grade 1B) }\end{array}$ & $\begin{array}{l}12 \mathrm{~h} \\
\text { preoperative } \\
\text { or } 12 \mathrm{~h} \\
\text { postoperative } \\
\text { (Very Low) }\end{array}$ & - & $\begin{array}{l}\text { WG (Time } \\
\text { depending on the } \\
\text { adopted regimen) }\end{array}$ \\
\hline
\end{tabular}

Continued 
Table 4 Continued

\section{Recommendations*}

15. Duration of prophylaxis
AAOS 2011

NR (WG)

ACCP 2012

ASH 2019

Asian VTE CPG

A minimum of 10 to 14 days (Grade 1B-1C)

19-42 days

2017

COA 2016

Up to 35 days

(Grade 2B)

16. General measures of thromboprophylaxis

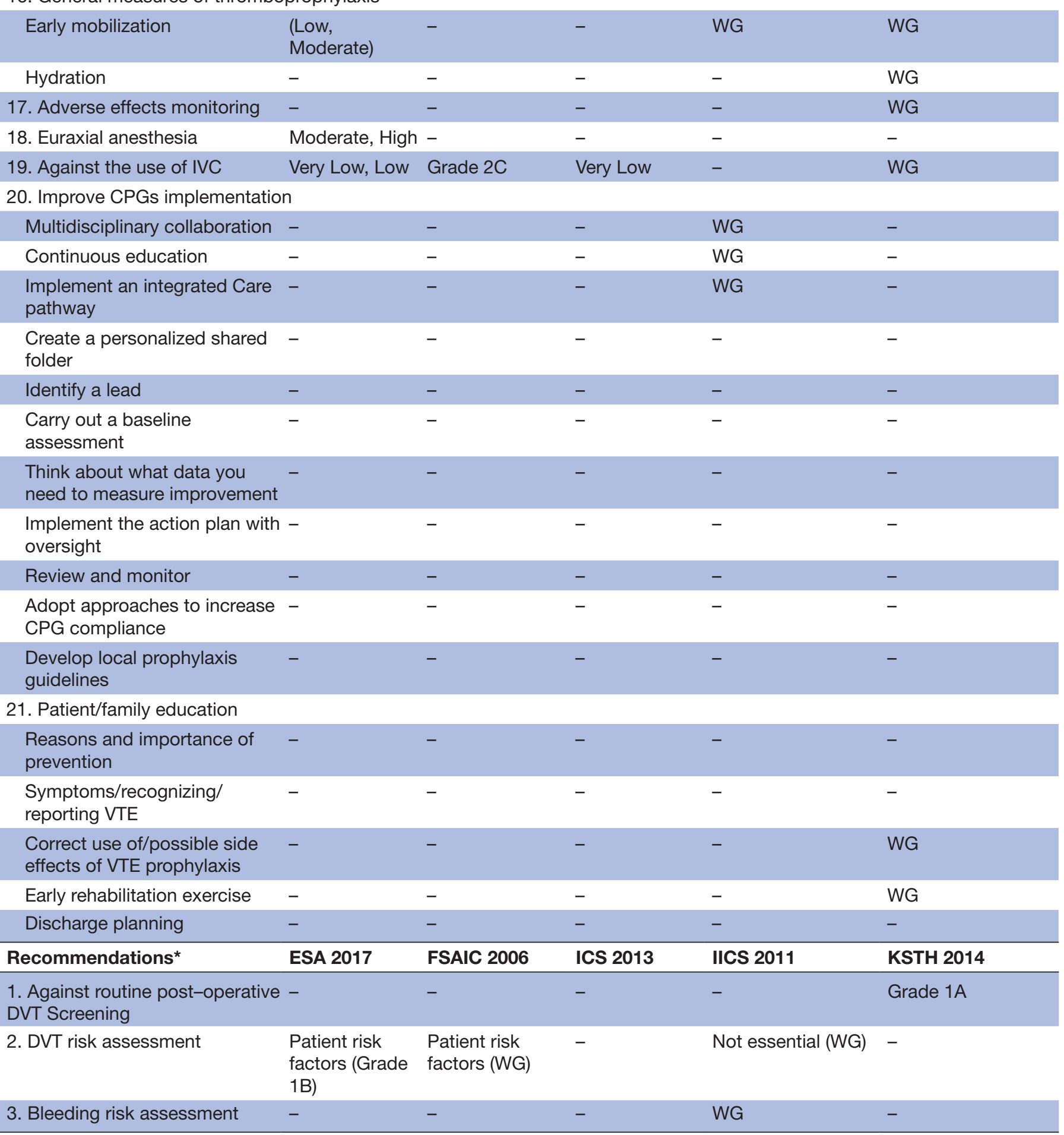

Continued

A minimum of 10 to 14 days, up to 35 days for THA (WG) 
Table 4 Continued

Recommendations*

ESA 2017

FSAIC 2006

ICS 2013

IICS 2011

KSTH 2014

4. Bridging therapy

$-$

NR (Low)

Consultation by specialists (WG)

\section{Stopping oestrogen-} containing oral contraceptives or hormone replacement therapy

6. Provide pharmacologic and/or
mechanical prophylaxis

7 Thromboprophylaxis for

patients with bleeding risk

(Grade 1B-2C)

Grade A-B

LMWH and

WG

Grade 2A, 2B IPCD (Grade 2C)

IPCD (High)

8. Pharmacological prophylaxis preference choice $†$

Mechanical prophylaxis

IPCD or FIT Mechanical (Grade A) combined with prophylaxis (WG) GES (High)

Mechanical

\section{LMWH (Grade LMWH (Grade A) -}

2B)

\section{Mechanical prophylaxis preference choice $†$}

10. Evaluation of pharmacological prophylaxis contraindications

\begin{tabular}{|c|c|c|c|c|c|}
\hline $\begin{array}{l}\text { 11. Evaluation of mechanical } \\
\text { prophylaxis contraindications }\end{array}$ & - & - & - & WG & - \\
\hline $\begin{array}{l}\text { 12. Use the fitted/correct size of } \\
\text { GCS }\end{array}$ & - & - & - & - & - \\
\hline $\begin{array}{l}\text { 13. Correct use of mechanical } \\
\text { prophylaxis }\end{array}$ & - & - & - & WG & - \\
\hline 14. Early or delayed prophylaxis & $\begin{array}{l}12 \mathrm{~h} \\
\text { preoperative or } \\
6-8 \mathrm{~h} \text { (Grade } \\
2 \mathrm{C})\end{array}$ & $\begin{array}{l}\text { Grade B, C } \\
\text { (Time depending } \\
\text { on the adopted } \\
\text { regimen) ( }\end{array}$ & $\begin{array}{l}\text { High (Time } \\
\text { depending on } \\
\text { the adopted } \\
\text { regimen) }\end{array}$ & $\begin{array}{l}\text { WG (Time } \\
\text { depending on the } \\
\text { adopted regimen) }\end{array}$ & - \\
\hline 15. Duration of prophylaxis & $\begin{array}{l}\text { Up to } 28 \text { days } \\
\text { (Grade } 2 \mathrm{~B} \text { ) }\end{array}$ & $\begin{array}{l}\text { Up to } 42 \text { days } \\
\text { for THA (Grade } \\
\text { A) Up to } 14 \text { days } \\
\text { for TKA (Grade } \\
\text { B) }\end{array}$ & $\begin{array}{l}\text { Up to } 28-42 \\
\text { days for THA } \\
\text { (Low, High) }\end{array}$ & Up to 35 days (WG) & $\begin{array}{l}\text { A minimum of } 10 \text { to } \\
14 \text { days (Grade } 2 A)\end{array}$ \\
\hline
\end{tabular}

16. General measures of thromboprophylaxis

$\begin{array}{llllll}\text { Early mobilization } & \text { Grade 1B } & - & - & \text { WG } & \text { Grade 1A } \\ \text { Hydration } & \text { Grade 1B } & - & - & - & - \\ \text { 17. Adverse effects monitoring } & - & \text { WG } & \text { Moderate } & - & - \\ \text { 18. Euraxial anesthesia } & - & - & - & - & - \\ \text { 19. Against the use of IVC } & - & - & \text { Low } & - & - \\ \text { 20. Improve CPGs implementation } & - & & & - \\ \text { Multidisciplinary collaboration } & - & - & - & - & - \\ \text { Continuous education } & - & - & - & - & \text { WG } \\ \begin{array}{l}\text { Implement an integrated Care } \\ \text { pathway }\end{array} & - & - & - & - & - \\ \begin{array}{l}\text { Create a personalized shared } \\ \text { folder }\end{array} & - & - & - & - & - \\ \text { Identify a lead } & - & - & - & - & - \\ \begin{array}{l}\text { Carry out a baseline } \\ \text { assessment }\end{array} & - & - & - & -\end{array}$

Continued 
Table 4 Continued

\begin{tabular}{llllll}
\hline Recommendations* & ESA 2017 & FSAIC 2006 & ICS 2013 & IICS 2011 & KSTH 2014 \\
\hline Implement the action plan with & - & - & - & - \\
oversight & - & - & - & - & - \\
Review and monitor & - & - & - & - \\
$\begin{array}{l}\text { Adopt approaches to increase } \\
\text { CPG compliance }\end{array}$ & - & - & - \\
$\begin{array}{l}\text { Develop local prophylaxis } \\
\text { guidelines }\end{array}$ & - & - & & -
\end{tabular}

21. Patient/family education

\begin{tabular}{llllll}
$\begin{array}{l}\text { Reasons and importance of } \\
\text { prevention }\end{array}$ & - & - & - & WG & WG \\
$\begin{array}{l}\text { Symptoms/recognizing/ } \\
\text { reporting VTE }\end{array}$ & - & - & - & WG & - \\
$\begin{array}{l}\text { Correct use of/possible side } \\
\text { effects of VTE prophylaxis }\end{array}$ & - & - & - & - \\
$\begin{array}{l}\text { Early rehabilitation exercise } \\
\text { Discharge planning }\end{array}$ & - & - & - & - & - \\
\hline
\end{tabular}

\begin{tabular}{ll}
\hline Recommendations $^{*}$ & MHM 2013 \\
\hline 1. Against routine postoperative & - \\
DVT Screening &
\end{tabular}

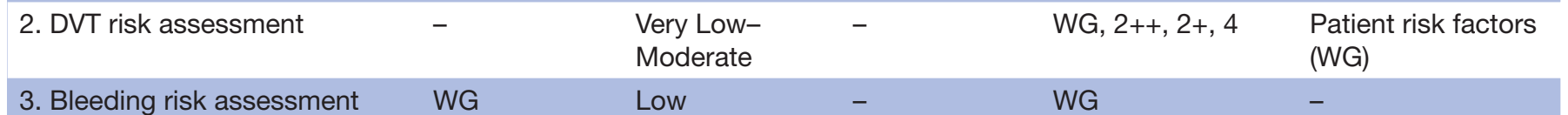

$\begin{array}{llllll}\text { 3. Bleeding risk assessment } & \text { WG } & \text { Low } & - & \text { WG } & - \\ \text { 4. Bridging therapy } & \text { Provide VTE } & \text { Provide VTE } & \text { Continuation } & - & \text { Switching between }\end{array}$
prophylaxis prophylaxis of antiplatelet anticoagulation (Ila-III) (Low-Moderate) preoperative modalities (WG)

(Class B) NR

about timing of anticoagulant withdrawal before the planned procedure (WG)

\section{Stopping oestrogen- containing oral contraceptives or hormone replacement therapy}

\begin{tabular}{|c|c|c|c|c|c|}
\hline $\begin{array}{l}\text { 6. Provide pharmacologic and/or } \\
\text { mechanical prophylaxis }\end{array}$ & la, Ib & Very Low-High & Class A & $1++-2+, 3,4$ & $\begin{array}{l}\text { pharmacologic and } \\
\text { IPCD (WG) }\end{array}$ \\
\hline $\begin{array}{l}7 \text { Thromboprophylaxis for } \\
\text { patients with bleeding risk }\end{array}$ & - & Very Low-Low & $\begin{array}{l}\text { IPCD or FIT } \\
\text { combined with } \\
\text { GES stockings } \\
\text { (Class A) }\end{array}$ & $1++, 1+, 2+$ & $\begin{array}{l}\text { IPCD or no } \\
\text { thromboprophylaxis } \\
\text { (WG) }\end{array}$ \\
\hline $\begin{array}{l}\text { 8. Pharmacological prophylaxis } \\
\text { preference choice } \dagger\end{array}$ & - & - & - & - & - \\
\hline $\begin{array}{l}\text { 10. Evaluation of } \\
\text { pharmacological prophylaxis } \\
\text { contraindications }\end{array}$ & - & - & - & - & - \\
\hline $\begin{array}{l}\text { 11. Evaluation of mechanical } \\
\text { prophylaxis contraindications }\end{array}$ & - & WG & - & WG & - \\
\hline
\end{tabular}

Continued 
Table 4 Continued

\begin{tabular}{llllll}
\hline Recommendations* & MHM 2013 & NICE 2019 & PCS 2017 & SIGN 2014 & SFSTH 2013 \\
\hline $\begin{array}{l}\text { 12. Use the fitted/correct size of } \\
\text { GCS }\end{array}$ & WG & - & WG & - \\
$\begin{array}{l}\text { 13. Correct use of mechanical } \\
\text { prophylaxis }\end{array}$ & - & WG & - & WG & -
\end{tabular}

\begin{tabular}{|c|c|c|c|c|c|}
\hline 14. Early or delayed prophylaxis & $\begin{array}{l}\text { Ila, Ilb and } \\
\text { III (Time } \\
\text { depending on } \\
\text { the adopted } \\
\text { regimen) }\end{array}$ & - & $\begin{array}{l}\text { Class A (Time } \\
\text { depending on } \\
\text { the adopted } \\
\text { regimen) }\end{array}$ & - & $\begin{array}{l}12 \text { h postoperative } \\
\text { (WG) }\end{array}$ \\
\hline 15. Duration of prophylaxis & $\begin{array}{l}\text { Up to } 35 \text { days } \\
\text { (la-IV) }\end{array}$ & $\begin{array}{l}\text { Up to } 28-38 \\
\text { days for THA } \\
\text { (Very Low- } \\
\text { Moderate) Up } \\
\text { to } 14 \text { days for } \\
\text { TKA (Very Low- } \\
\text { Moderate) }\end{array}$ & $\begin{array}{l}\text { Up to } 35 \text { days } \\
\text { for THA (Class } \\
\text { B) Up to } 14 \\
\text { days for TKA } \\
\text { (Class B) }\end{array}$ & $\begin{array}{l}\text { Extended } \\
\text { prophylaxis }(1++, \\
1+, 4)\end{array}$ & $\begin{array}{l}\text { Up to } 35 \text { days for } \\
\text { THA (WG) Up to } 14 \\
\text { days for TKA (WG) }\end{array}$ \\
\hline
\end{tabular}

16. General measures of thromboprophylaxis

\begin{tabular}{|c|c|c|c|c|c|}
\hline Early mobilization & - & WG & - & $2+, 1+$ & - \\
\hline Hydration & - & WG & - & 4 & - \\
\hline 17. Adverse effects monitoring & la-IV & - & Cass C & WG, 4 & WG \\
\hline 18. Euraxial anesthesia & - & - & - & - & - \\
\hline 19. Against the use of IVC & - & - & - & - & - \\
\hline \multicolumn{6}{|l|}{ 20. Improve CPGs implementation } \\
\hline Multidisciplinary collaboration & - & WG & - & - & - \\
\hline Continuous education & - & WG & - & - & - \\
\hline $\begin{array}{l}\text { Implement an integrated Care } \\
\text { pathway }\end{array}$ & - & WG & - & - & - \\
\hline $\begin{array}{l}\text { Create a personalized shared } \\
\text { folder }\end{array}$ & - & - & - & - & - \\
\hline Identify a lead & - & WG & - & - & - \\
\hline $\begin{array}{l}\text { Carry out a baseline } \\
\text { assessment }\end{array}$ & - & WG & - & WG & - \\
\hline $\begin{array}{l}\text { Think about what data you } \\
\text { need to measure improvement }\end{array}$ & - & WG & - & - & - \\
\hline $\begin{array}{l}\text { Implement the action plan with } \\
\text { oversight }\end{array}$ & - & WG & - & - & - \\
\hline Review and monitor & - & WG & - & - & - \\
\hline $\begin{array}{l}\text { Adopt approaches to increase } \\
\text { CPG compliance }\end{array}$ & - & - & - & $1+, 2++$ & - \\
\hline $\begin{array}{l}\text { Develop local prophylaxis } \\
\text { guidelines }\end{array}$ & - & - & - & $1+, 2++$ & - \\
\hline \multicolumn{6}{|l|}{ 21. Patient/family education } \\
\hline $\begin{array}{l}\text { Reasons and importance of } \\
\text { prevention }\end{array}$ & - & Very Low & - & WG & - \\
\hline $\begin{array}{l}\text { Symptoms/recognizing/ } \\
\text { reporting VTE }\end{array}$ & - & Very Low & - & WG & - \\
\hline $\begin{array}{l}\text { Correct use of/possible side } \\
\text { effects of VTE prophylaxis }\end{array}$ & - & Very Low & - & WG & - \\
\hline Early rehabilitation exercise & - & Very Low & - & - & - \\
\hline Discharge planning & - & WG & - & - & - \\
\hline
\end{tabular}


Table 4 Continued

\begin{tabular}{llllll} 
Recommendations* $^{*}$ & MHM 2013 & NICE 2019 & PCS 2017 & SIGN 2014 & SFSTH 2013 \\
\hline
\end{tabular}

${ }^{*}$ Refer to Appendix 6 for the recommendations from each CPG that informed in Table 4 and Appendix 7 for an explanation of the different evidence levels.

†For more prophylaxis choice please refer to Appendix 6-Specific recommendations across all CPGs that informed in Table 4. -, Not reported; AAOS, American Academy of Orthopaedic Surgeons; ACCP, American College of Chest Physicians; ASH, American Society of Hematology; COA, Chinese Orthopaedic Association; CPG, clinical practice guideline; CPGs, clinical practice guidelines; DOACs, direct oral anticoagulants; ECS, elastic compression; ESA, European Society of Anaesthesiology; FIT, foot impulse technology; FSAIC, French Society for Anaesthesiology and Intensive Care; GCS, graduated compression stockings; ICS, International Consensus Statement; IICS, Italian intersociety consensus statement; IPCD, intermittent pneumatic compression device; IVC, inferior vena cava; KSTH, Korean Society of Thrombosis and Hemostasis; LMWH, low-molecular-weight heparin; MHM, Ministry of Health Malaysia; NICE, National Institute for Health and Care Excellence; NR, No recommendation/unresolved issue; PCS, Polish Consensus Statement; SFSTH, Southern African Society of Thrombosis and Haemostasis; SIGN, Scottish Intercollegiate Guidelines Network; THA, total hip arthroplasty; TKA, total knee arthroplasty; VTE, venous thromboembolism; WG, Working group expert opinion.

the Applicability domain. Finally, improving CPG implementation and sustainability should also be carefully considered in CPG development.

\section{Author affiliations}

${ }^{1}$ Department of Nursing, Chinese Academy of Medical Sciences - Peking Union Medical College, Peking Union Medical College Hospital, Beijing, China

${ }^{2}$ Department of Cardiac Surgery, Chinese Academy of Medical Sciences - Peking Union Medical College, Peking Union Medical College Hospital, Beijing, China ${ }^{3}$ Department of Orthopedic Surgery, Chinese Academy of Medical Sciences - Peking Union Medical College, Peking Union Medical College Hospital, Beijing, China ${ }^{4}$ Department of Vascular Surgery, Chinese Academy of Medical Sciences - Peking Union Medical College, Peking Union Medical College Hospital, Beijing, China ${ }^{5}$ Department of Breast Surgery, Chinese Academy of Medical Sciences - Peking Union Medical College, Peking Union Medical College Hospital, Beijing, China

${ }^{6}$ School of Nursing, Peking University, Beijing, China

${ }^{7}$ Evidence-Based Nursing: A Joanna Briggs Institute Centre of Excellence, Peking University Health Science Centre, Beijing, China

${ }^{8}$ Intensive Care Unit, Chinese Academy of Medical Sciences - Peking Union Medical College, Peking Union Medical College Hospital, Beijing, China

${ }^{9}$ Department of Neurological Surgery, Chinese Academy of Medical Sciences Peking Union Medical College, Peking Union Medical College Hospital, Beijing, China ${ }^{10}$ Department of General Surgery, Chinese Academy of Medical Sciences - Peking Union Medical College, Peking Union Medical College Hospital, Beijing, China

${ }^{11}$ Outpatient Department, Chinese Academy of Medical Sciences - Peking Union Medical College, Peking Union Medical College Hospital, Beijing, China

Contributors YW, LYZ, YX, XJW, JHS, HBD, YFM and XJW designed the study, critically appraised the guidelines and collected the data. XY, LW, JC, GL and YL collected the data. DP interpreted the data. YW, LYZ, YX, XJW and JHS wrote the first draft. XY, LW, JC, DP, GL, YL and HBD conducted the systemic review and revised the manuscript. All authors contributed to subsequent versions and approved the final manuscript.

Funding The authors have not declared a specific grant for this research from any funding agency in the public, commercial or not-for-profit sectors.

Competing interests None declared.

Patient consent for publication Not required.

Provenance and peer review Not commissioned; externally peer reviewed.

Data availability statement All data relevant to the study are included in the article or uploaded as supplementary information. The data set supporting the conclusions of this article is included in the article.

Supplemental material This content has been supplied by the author(s). It has not been vetted by BMJ Publishing Group Limited (BMJ) and may not have been peer-reviewed. Any opinions or recommendations discussed are solely those of the author(s) and are not endorsed by BMJ. BMJ disclaims all liability and responsibility arising from any reliance placed on the content. Where the content includes any translated material, BMJ does not warrant the accuracy and reliability of the translations (including but not limited to local regulations, clinical guidelines, terminology, drug names and drug dosages), and is not responsible for any error and/or omissions arising from translation and adaptation or otherwise.

Open access This is an open access article distributed in accordance with the Creative Commons Attribution Non Commercial (CC BY-NC 4.0) license, which permits others to distribute, remix, adapt, build upon this work non-commercially, and license their derivative works on different terms, provided the original work is properly cited, appropriate credit is given, any changes made indicated, and the use is non-commercial. See: http://creativecommons.org/licenses/by-nc/4.0/.

ORCID iD

Xin-Juan Wu http://orcid.org/0000-0002-9024-7941

\section{REFERENCES}

1 Cordtz R, Odgaard A, Kristensen LE, et al. Risk of medical complications following total hip or knee arthroplasty in patients with rheumatoid arthritis: a register-based cohort study from Denmark. Semin Arthritis Rheum 2020;50:30-5.

2 Cordtz RL, Zobbe K, Højgaard P, et al. Predictors of revision, prosthetic joint infection and mortality following total hip or total knee arthroplasty in patients with rheumatoid arthritis: a nationwide cohort study using Danish healthcare registers. Ann Rheum Dis 2018;77:281-8.

3 Ravi B, Escott B, Shah PS, et al. A systematic review and metaanalysis comparing complications following total joint arthroplasty for rheumatoid arthritis versus for osteoarthritis. Arthritis Rheum 2012;64:3839-49.

4 Falck-Ytter Y, Francis CW, Johanson NA, et al. Prevention of VTe in orthopedic surgery patients: antithrombotic therapy and prevention of thrombosis, 9th ED: American College of chest physicians evidence-based clinical practice guidelines. Chest2012;141:e27 8S-325.

5 Geerts WH, Bergqvist D, Pineo GF, et al. Prevention of venous thromboembolism: American College of chest physicians evidence-based clinical practice guidelines (8th edition). Chest 2008;133:381s-453.

6 Shahi A, Bradbury TL, Guild GN, et al. What are the incidence and risk factors of in-hospital mortality after venous thromboembolism events in total hip and knee arthroplasty patients? Arthroplast Today 2018;4:343-7.

7 Shahi A, Chen AF, Tan TL, et al. The incidence and economic burden of in-hospital venous thromboembolism in the United States. $J$ Arthroplasty 2017;32:1063-6.

8 Sanders JO, Bozic KJ, Glassman SD, et al. Clinical practice guidelines: their use, misuse, and future directions. J Am Acad Orthop Surg 2014:22:135-44.

9 Moher Det al. Preferred reporting items for systematic reviews and meta-analyses: the PRISMA statement (Chinese edition). J Chin Integr Med 2009;7:889-96.

10 Brouwers MC, Kho ME, Browman GP, et al. Development of the agree II, part 1: performance, usefulness and areas for improvement. CMAJ 2010;182:1045-52.

11 The AGREE Next Steps Consortium. Agree II translations (Chinese), 2009. Available: https://www.agreetrust.org/resource-centre/agree-ii/ [Accessed 5 May 2020]. 
12 The AGREE Next Steps Consortium. Agree II overview tutorial. Available: http://agree2.machealth.ca/players/open/index.html [Accessed 5 May 2020].

13 The AGREE Next Steps Consortium. My agree plus. Available: https://www.agreetrust.org/my-agree/ [Accessed 5 May 2020].

14 Landis JR, Koch GG. The measurement of observer agreement for categorical data. Biometrics 1977;33:159-74.

15 Anderson DR, Morgano GP, Bennett C, et al. American Society of hematology 2019 guidelines for management of venous thromboembolism: prevention of venous thromboembolism in surgical hospitalized patients. Blood Adv 2019;3:3898-944.

16 Falck-Ytter Y, Francis CW, Johanson NA, et al. Prevention of VTe in orthopedic surgery patients: antithrombotic therapy and prevention of thrombosis, 9th ED: American College of chest physicians evidence-based clinical practice guidelines. Chest 2012;141:e27 8S-325.

17 Jacobs JJ, Mont MA, Bozic KJ, et al. American Academy of orthopaedic surgeons clinical practice guideline on: preventing venous thromboembolic disease in patients undergoing elective hip and knee arthroplasty. J Bone Joint Surg Am 2012;94:746-7.

18 Chinese Medical Association Orthopedics Branch. Guidelines for prevention of venous thromboembolism in major orthopedic surgery in China. Chinese J Orthopaed 2016;2:65-71.

19 National Institute for Health and Care Excellence. Venous thromboembolism in over 16S: reducing the risk of hospital-acquired deep vein thrombosis or pulmonary embolism, 2019. Available: https://www.nice.org.uk/guidance/NG89 [Accessed 5 May 2020].

20 Samama CM, Albaladejo P, Benhamou D, et al. Venous thromboembolism prevention in surgery and obstetrics: clinical practice guidelines. Eur J Anaesthesiol 2006;23:95-116.

21 Tomkowski W, Kuca P, Urbanek T, et al. Venous thromboembolism - recommendations on the prevention, diagnostic approach and management. The 2017 Polish consensus statement. Acta Angiologica 2017;23:35-71.

22 Ministry of Health Malaysia. Prevention and treatment of venous thromboembolism, 2013. Available: https://haematology.org.my/ docs/VTE\%20CPG\%202013.pdf [Accessed 5 May 2020].

23 Bang S-M, Jang MJ, Kim KH, et al. Prevention of venous thromboembolism, 2nd edition: Korean Society of thrombosis and hemostasis evidence-based clinical practice guidelines. J Korean Med Sci 2014;29:164-71.

24 Della Rocca G, Danelli G, Randelli F, et al. II Italian intersociety consensus statement on antithrombotic prophylaxis in orthopedics and traumatology. Minerva Anestesiol 2013;79:778-92.

25 Scottish Intercollegiate Guidelines Network. Prevention and management of venous thromboembolism, 2014. Available: https:// www.sign.ac.uk/assets/sign122.pdf [Accessed 5 May 2020].

26 Jacobson BF, Louw S, Büller $\mathrm{H}$, et al. Venous thromboembolism: prophylactic and therapeutic practice guideline. S Afr Med J 2013;103:260-7.

27 Liew NC, Alemany GV, Angchaisuksiri P, et al. Asian venous thromboembolism guidelines: updated recommendations for the prevention of venous thromboembolism. Int Angiol 2017;36:1-20.

28 Venclauskas L, Llau JV, Jenny J-Y, et al. European guidelines on perioperative venous thromboembolism prophylaxis: day surgery and fast-track surgery. Eur J Anaesthesiol 2018;35:134-8.

29 Cardiovascular Disease Educational and Research Trust, European Venous Forum, North American Thrombosis Forum. Prevention and treatment of venous thromboembolism: international consensus statement, 2013. Available: https://europeanvenousforum.org/wpcontent/uploads/2015\%2012F2002\%2012FIUA_Guidelines_2013. pdf [Accessed 5 May 2020].

30 Barton S. Which clinical studies provide the best evidence? the best RCT still trumps the best observational study. BMJ 2000;321:255-6.

31 Farfan M, Bautista M, Bonilla G, et al. Worldwide adherence to ACCP guidelines for thromboprophylaxis after major orthopedic surgery: a systematic review of the literature and meta-analysis. Thromb Res 2016;141:163-70.

32 Lockwood R, Kable A, Hunter S. Evaluation of a nurse-led intervention to improve adherence to recommended guidelines for prevention of venous thromboembolism for hip and knee arthroplasty patients: a quasi-experimental study. J Clin Nurs 2018;27:e1048-60.

33 Gillespie BM, Bull C, Walker R, et al. Quality appraisal of clinical guidelines for surgical site infection prevention: a systematic review. PLoS One 2018;13:e0203354.

34 Zheng J, Chen Q, Fu J, et al. Critical appraisal of international guidelines for the prevention and treatment of pregnancy-associated venous thromboembolism: a systematic review. BMC Cardiovasc Disord 2019;19:199-99.

35 World Health Organization. Handbook for Guideline development. Available: https://www.who.int/publications/guidelines/handbook-forguideline-development/zh/ [Accessed 5 May 2020].

36 Brouwers MC, Kho ME, Browman GP, et al. Agree II: advancing Guideline development, reporting and evaluation in health care. CMAJ 2010;182:E839-42.

37 Shin JJ. Involving stakeholders in the development of clinical practice guidelines. Otolaryngol Head Neck Surg 2014;150:907-9.

38 Grimshaw JM, Thomas RE, MacLennan G, et al. Effectiveness and efficiency of guideline dissemination and implementation strategies. Health Technol Assess 2004;8:1-72.

39 Greenhalgh T, Howick J, Maskrey N, et al. Evidence based medicine: a movement in crisis? BMJ 2014;348:g3725.

40 Roy P-M, Rachas A, Meyer G, et al. Multifaceted intervention to prevent venous thromboembolism in patients hospitalized for acute medical illness: a multicenter cluster-randomized trial. PLoS One 2016;11:e0154832

41 Fontaine A, Mahé I, Bergmann JF, et al. Effectiveness of written guidelines on the appropriateness of thromboprophylaxis prescriptions for medical patients: a prospective randomized study. $J$ Intern Med 2006;260:369-76.

42 Labarere J, Bosson J-L, Sevestre M-A, et al. Intervention targeted at nurses to improve venous thromboprophylaxis. Int J Qual Health Care 2007;19:301-8.

43 Boddi M, Barbani F, Abbate R, et al. Reduction in deep vein thrombosis incidence in intensive care after a clinician education program. J Thromb Haemost 2010;8:121-8.

44 Zhao W, McArthur A, Yu Z, et al. Prevention of venous thromboembolism in postoperative abdominal patients: a best practice implementation project. JBI Database System Rev Implement Rep 2018;16:1887-901.

45 Kahn SR, Morrison DR, Cohen JM, et al. Interventions for implementation of thromboprophylaxis in hospitalized medical and surgical patients at risk for venous thromboembolism. Cochrane Database Syst Rev 2013;7:Cd008201.

46 Kahn SR, Morrison DR, Diendéré G, et al. Interventions for implementation of thromboprophylaxis in hospitalized patients at risk for venous thromboembolism. Cochrane Database Syst Rev 2018;4:Cd008201.

47 Australian Commission on Safety and Quality in Health Care. Venous thromboembolism prevention clinical care standard, 2020. Available: https://www.safetyandquality.gov.au/publications-and-resources/ resource-library/venous-thromboembolism-prevention-clinical-carestandard [Accessed 5 May 2020].

48 The Australia \& New Zealand Working Party. Prevention of venous thromboembolism, 2007. Available: chrome-extension:// ikhdkkncnoglghljlkmcimlnlhkeamad/pdf-viewer/web/viewer.html? file=https $\% 3 A \% 2 F \% 2 F n z o a . o r g . n z \% 2 F s y s t e m \% 2 F f i l e s \% 2 F V T E$ Guidelines.pdf [Accessed 5 May 2020].

49 Ginzburg E, Banovac K, Epstein B, et al. Thromboprophylaxis in medical and surgical patients undergoing physical medicine and rehabilitation: consensus recommendations. Am J Phys Med Rehabil 2006;85:159-66. 